\title{
Is the IS 1-flanked r-Determinant of the R Plasmid NR 1 a Transposon?
}

\author{
By SHIGERU IIDA, * CHRISTINE H ÄNNI, CHRISTINE ECHARTI $\dagger$ \\ AND WERNER ARBER \\ Department of Microbiology, Biozentrum, University of Basel, Klingelbergstrasse 70, \\ CH-4056 Basel, Switzerland
}

(Received 11 December 1980; revised 10 March 1981)

\begin{abstract}
The 23 kilobase multiple drug resistance $r$-determinant ( $r$-det) of the $R$ plasmid NR 1 is an IS1-mediated transposon, Tn2671. Drug-resistant Escherichia coli transductants isolated after infection with bacteriophage $\mathrm{P} 1:: \operatorname{Tn} 2671$ derivatives carry the intact $\mathrm{r}$-det in their chromosomes. Independently isolated transductants carry the r-det at different locations on the chromosome. From the $E$. coli chromosome, Tn2671 can transpose to various locations on the phage P7 genome. Throughout these processes, $r$-det is maintained as a stable unit. Various possible molecular mechanisms, which all might contribute with characteristic frequencies to the transposition of $\operatorname{Tn} 2671$, are discussed. The results presented are relevant to the understanding of mechanisms for a wide spreading of drug resistance genes.
\end{abstract}

\section{INTRODUCTION}

Genes coding for antibiotic resistance in bacteria have often been shown to transpose from one replicon to another independently of genetic homology. The movable, genetically stable DNA segments containing these genes have been defined as transposons (Berg, 1977; Botstein \& Kleckner, 1977; Brevet et al., 1977; Campbell et al., 1977; Heffron et al., 1977). Some but not all transposons are flanked by IS elements. For example, two directly repeated IS elements form the ends of $\mathrm{Tn} 9$, which carried a determinant for chloramphenicol resistance (MacHattie \& Jackowski, 1977). Two parallel IS 1 elements are also carried in the R plasmid NR 1, where they flank a DNA segment more than 20 kilobases $(\mathrm{kb})$ long, which is called the $\mathrm{r}$-determinant ( $\mathrm{r}$-det), since it contains determinants for resistance to chloramphenicol $(\mathrm{Cm})$, fusidic acid $(\mathrm{Fa})$, streptomycin $(\mathrm{Sm})$, sulphonamide $(\mathrm{Su})$ and mercury $(\mathrm{Hg})(\mathrm{Hu}$ et al., 1975 ; Ptashne \& Cohen, 1975; Lane \& Chandler, 1977; Arber et al., 1978; Miki et al., 1978).

Iida \& Arber (1977) characterized oversized, specialized transducing P1 phage genomes, which had been isolated after growth of P1 in NR 1-containing bacteria. In transduction, these phages render their host cells resistant to $\mathrm{Cm}, \mathrm{Sm}, \mathrm{Su}, \mathrm{Fa}$ and $\mathrm{Hg}$ (Iida \& Arber, 1980). Restriction cleavage analysis revealed that such ' $\mathrm{P} 1 \mathrm{CmFaSmSuHg}$ ' phages carry the intact r-det of the parental NR 1 plasmid (Iida \& Arber, 1980; S. Iida \& J. Meyer, unpublished results). Many antibiotic-resistant transductants obtained by single infection with such transducing phage lysates revealed none of several P1 traits tested (Iida \& Arber, 1977). It had been assumed therefore that these transduction products carried the $r$-det translocated into the chromosome. Here we present experimental evidence for this hypothesis and that the $r$-det can again transpose from its chromosomal location on to another replicon. Since its flanking IS1 elements can serve as sites of action for IS1-specific transposase as well as in reciprocal recombination with other IS 1 elements, more than one molecular mechanism can bring about the translocation of $r$-det as a unit.

\footnotetext{
† Present address: Max-Planck-Institut für Molekulare Genetik, Ihnestrasse 63-73, D-1000 Berlin 33, Federal Republic of Germany.
} 


\section{Table 1. Bacteria, $R$ plasmids and phage strains}

Nomenclature is according to the recommendations of Bachmann et al. (1976) and Novick et al. (1976).

Strain

Relevant characters

Source/reference

\begin{tabular}{|c|c|}
\hline \multicolumn{2}{|l|}{ Bacteria* } \\
\hline LC 102 & $\left(\mathrm{~F}^{-}\right)$leu proC purE trp his argG rpsL ilv metA \\
\hline $\mathrm{CH} 104$ & LC102 rpoB \\
\hline WA921 & $\left(\mathrm{F}^{-}\right)$thr leu met thi hsd $d_{\mathrm{K}}$ \\
\hline W3110(ג) & Prototroph $(\lambda)$ \\
\hline WA3573 & W3110 ilv::r-det mer $(\lambda)$ \\
\hline WA3574 & W3110 his : :r-det $(\lambda)$ \\
\hline WA3575 & $\begin{array}{l}\text { W3110: : r-det, carrying an unidentified } \\
\text { auxotrophy mutation }(\lambda)\end{array}$ \\
\hline WA3594 & $\mathrm{Hfr} 3000(=\mathrm{HfrH})$ \\
\hline WA3767 & WA3594: :r-det \\
\hline WA3768 & WA3594: :r-det \\
\hline WA 3769 & WA3594: : r-det \\
\hline \multicolumn{2}{|l|}{ R plasmids } \\
\hline $\mathrm{R} 100-1 d r d$ & $\mathrm{cat}^{+} \mathrm{fus}^{+} \mathrm{aad}^{+} \mathrm{sul}^{+} \mathrm{mer}^{+}$on $\mathrm{r}-\operatorname{det} \dagger, \mathrm{Tn} 10, \mathrm{Tra}^{+}$ \\
\hline NR1-Basel & $\mathrm{cat}^{+}$fus $^{+} \mathrm{aad}^{+} \mathrm{sul}^{+} \mathrm{mer}^{+}$on $\mathrm{r}-\operatorname{det}^{\dagger}, \mathrm{Tn} 10, \mathrm{Tra}^{+}$ \\
\hline \multicolumn{2}{|l|}{ Phages } \\
\hline \multicolumn{2}{|l|}{ P1clts 225} \\
\hline \multicolumn{2}{|l|}{ Plclts 162} \\
\hline P1res(P1):: r-det56clts 225 & $\begin{array}{l}\mathrm{r} \text {-det inserted within the } \operatorname{res}(\mathrm{P} 1) \text { structural gene } \\
\text { causing a } \operatorname{Res}^{-}(\mathrm{P} 1) \mathrm{Mod}^{+}(\mathrm{P} 1) \text { phenotype }\end{array}$ \\
\hline P1-r-det $81 c l t s 225$ & r-det carried at the resident IS 1 of $\mathrm{Pl}$ \\
\hline P7clts 48 & Carrying Tn902Ap ${ }^{r}$ \\
\hline P7bla: :r-det204clts 48 & $\begin{array}{l}\text { Carrying r-det from WA3768 within the bla } \\
\text { gene of Tn } 902 \text {, has Aps phenotype }\end{array}$ \\
\hline P7: :r-det $207 c / t s 48$ & $\begin{array}{l}\text { r-det from WA3769, also carries a mutation in } \\
\text { res }(\mathrm{P} 1) \text { causing a Res } \\
\text { phenotype }\end{array}$ \\
\hline P7::r-det209clts 48 & r-det from WA3768 \\
\hline
\end{tabular}

L. Caro

This study

Wood (1966)

Our collection

This study

This study

This study

B. Bachmann CGSC 259

This study

This study

This study

Egawa \& Hirota (1962)

Arber et al. (1978)

Scott (1968)

Scott (1968)

lida \& Arber (1980)

Iida \& Arber (1980)

Wandersman \& Yarmolinsky (1977)

This study

This study

This study

* All bacterial strains derived from $E$. coli K 12 .

† The r-det of NR1-Basel is defined in this paper as IS1-mediated transposon Tn2671. It differs from the r-det of R100-1 by its carrying an internal $1.25 \mathrm{~kb}$ IS element, now called IS30 (Arber et al., 1978). It is unlikely that IS30 plays any role in the transposition of $\operatorname{Tn} 2671$ as a unit, since deletion derivatives of $\operatorname{Tn} 2671$ not carrying IS30 are also transposons (Arber et al., 1978; Iida \& Arber, 1980). The IS1-flanked r-det of R 100-1 is also likely to be a transposon, which we propose to call $\operatorname{Tn} 2670$.

\section{METHODS}

Microbial strains and media. The Escherichia coli strains, the plasmids and the bacteriophage strains used are listed in Table 1. Growth media were as described by Iida \& Arber (1977). Chloramphenicol, $\mathrm{HgCl}_{2}$ and ampicillin were added at $25 \mu \mathrm{g} \mathrm{ml}^{-1}, 25 \mu \mathrm{g} \mathrm{ml}^{-1}$ and $200 \mu \mathrm{g} \mathrm{ml}^{-1}$, respectively, to LB agar without glucose or $\mathrm{CaCl}_{2}$.

Phage and genetic methods. Preparation of phage lysates by heat induction, phage titration, measurement of killer production, plaque centre tests, restriction and modification tests, determination of immunity and transduction were done as described by Iida \& Arber (1977).

Enrichment and isolation of P7::r-det from lysates of phage P7 grown on bacteria with $r$-det inserted in the chromosome was achieved in alternating steps of transduction and induction with selection for $\mathrm{Cm}^{\mathrm{r}}$ (Iida \& Arber, 1977). Since P7::r-det is expected to have a so-called 'oversized' phage genome which cannot be packaged intact into P7 phage particles, the multiplicity of infection was kept high in these cycling experiments in order to assure the transmission of entire genomes through recombinational reconstitution (Iida, 1980).

Matings with Hfr strains as donors were performed as described by Miller (1972). For mating with plasmid transconjugants as donors, R100-1, an NR1 derivative displaying derepressed transfer activity (Egawa \& Hirota, 1962), was transferred by conjugation into strains WA3573, WA3574 and WA3575 and their parent W3110( $\lambda)$. The resulting derivatives were grown to a density of $2 \times 10^{8}$ cells $\mathrm{ml}^{-1}$ and gently shaken with strain $\mathrm{CH} 104$ for 
$90 \mathrm{~min}$. The mating mixture was diluted and plated on Davis minimal agar containing $80 \mu \mathrm{g}$ rifampicin $\mathrm{ml}^{-1}$ and appropriate nutritional supplements. $\mathrm{Leu}^{+}, \mathrm{Pro}^{+}, \mathrm{Trp}^{+}, \mathrm{His}^{+}, \mathrm{Arg}^{+}$or $\mathrm{Met}^{+}$recombinants were then scored.

Restriction cleavage analysis and filter hybridization of DNA. Preparation of phage DNA, cleavage with restriction endonucleases and gel electrophoresis were carried out as described by Meyer \& Iida (1979). Restriction endonucleases were obtained from T. A. Bickle or purchased from New England Biolabs.

Preparation of ${ }^{32} \mathrm{P}$-labelled DNA by nick-translation, and transfer of DNA from agarose slab gels to nitrocellulose filters were done according to Iida \& Arber (1980).

\section{RESULTS}

Isolation and physiological characterization of $\mathrm{Cm}^{r}$ transductants of WA3594 and W3110( $\left.\lambda\right)$

Phage P1 derivatives carrying $r$-det were used to transduce the strains WA3594 and W3110 $(\lambda)$ for $\mathrm{Cm}^{\mathrm{r}}$. The transductants were first characterized with regard to P1-specified phage traits and antibiotic resistance characters.

The HfrH strain WA3594 was chosen as recipient in order to facilitate the mapping of $\mathrm{r}$-det segments inserted into the bacterial chromosome. $\mathrm{Cm}^{\mathrm{r}}$ transductants appeared with a frequency of about five per plaque-forming unit when the cells were infected with $\mathrm{K}$-modified P1-r-det81 or P1::r-det56 at a multiplicity of $8 \times 10^{-5}$ plaque-forming phages per cell, roughly corresponding to 0.03 phage particles per cell (Iida \& Arber, 1977). About $15 \%$ of the $\mathrm{Cm}^{r}$ transductants grew as large colonies, and about $85 \%$ as small colonies. Most of the $\mathrm{Cm}^{\mathrm{r}}$ transductants forming large colonies (42 out of 45 colonies tested) displayed $\mathrm{Cm}^{\mathrm{r}} \mathrm{Sm}^{\mathrm{r}} \mathrm{Su}^{\mathrm{r}} \mathrm{Hg}^{\mathrm{r}}, \mathrm{P} 1$ immune and $\mathrm{Res}^{+}(\mathrm{P} 1) \mathrm{Mod}^{+}(\mathrm{P} 1)$ phenotypes and produced $\mathrm{P} 1$ phage upon incubation at $42^{\circ} \mathrm{C}$ (Table 2 ). It is thus likely that they originated from lysogenization with $\mathrm{P} 1$ carrying $\mathrm{r}$-det.

As mentioned above, a majority of $\mathrm{Cm}^{\mathrm{r}}$ transductants of strain WA3594 appeared as small colonies. However upon purification, these $\mathrm{Cm}^{\mathrm{r}}$ bacteria grew about as well as those isolated originally as large.colonies, indicating that the small colony size was likely to be due to a delay in the establishment of the transductant clones. None of 41 such transductants studied produced killer particles under induction conditions (Table 2). All but one of them displayed neither P1 immunity nor P1-specific restriction and modification, indicating that these transductants were not lysogenic for P1. A total of 22 strains were chosen as hosts for growth of P1clts 162. None of the resulting lysates transduced $\mathrm{Cm}^{\mathrm{r}}$ at high frequency (Table 2), suggesting that the drug resistance characters were not carried on a P1-related plasmid. Rather, the resistance genes might be integrated in the bacterial chromosome. Additional evidence for this interpretation will be given below. Table 2 also shows that 30 of the 41 transductants initially forming small colonies carried all four resistance characters, indicating the presence of the intact $\mathrm{r}$-det. The remaining 11 transductants with partial resistance phenotypes might have suffered deletions. In conclusion, the transductants which initially formed small colonies probably contained the r-det integrated into the chromosome.

In a second experiment, $\mathrm{Cm}^{5}$ transductant colonies of $\mathrm{W} 3110(\lambda)$ were screened for auxotrophs in order to obtain information about the target sites of the transposed $r$-det in the host chromosome. Among $5000 \mathrm{Cm}^{\mathrm{r}}$ transductants isolated after infection with P1-r-det81 [prepared from W3110(P1-r-det81)] at a multiplicity of $5 \times 10^{-6}$ plaque-forming phages per cell, only three auxotrophic mutants which showed no P1 character were found: WA3573, WA3574 and WA3575 (Table 1). Revertants to prototrophy appeared in two of these strains, WA3574 and WA3575, with frequencies of $10^{-9}$ per cell. All such revertants studied were sensitive to $\mathrm{Cm}, \mathrm{Sm}, \mathrm{Su}$ and $\mathrm{Hg}$, suggesting that excision and loss of the $\mathrm{r}$-det had occurred. No revertants to $i v^{+}$were obtained from WA3573. We consider that a deletion affecting the mer gene and part of $i l v$ could explain this lack of reversion. In addition, introduction, by transduction, of $h_{i}{ }^{+}$and $i v^{+}$markers from W3110 to WA3574 and WA3573, respectively, caused simultaneous loss of the drug-resistance markers. Thus it appears that the translocation of $\mathrm{r}$-det into the chromosome caused the respective auxotrophic mutations. 
Table 2. Characterization of $\mathrm{Cm}^{r}$ transductants of the HfrH strain WA3594

Two independent lysates ( $\mathrm{a}$ and b) of $\mathrm{P} 1-\mathrm{r}-\operatorname{det} 81 \cdot \mathrm{K}$ and one lysate of $\mathrm{P} 1:: \mathrm{r}-\operatorname{det} 56 \cdot \mathrm{K}$ were used to transduce strain WA3594. Large and small colony forming $\mathrm{Cm}^{\mathrm{r}}$ transductants were tested separately for their drug resistance patterns and for killer production $(\mathrm{kp})$, which is an indicator for heat-induced formation of phage particles (Iida \& Arber, 1977). Plate stock lysates of phage P1clts 162 were prepared at $42^{\circ} \mathrm{C}$ on non-killer producers and $\mathrm{Cm}^{r}$ transduction frequencies of the resulting lysates were tested with strain WA921. Low frequency of transduction was defined as $<2 \times 10^{-4} \mathrm{Cm}^{\mathrm{r}}$ transductants per plaque-forming phage. With a number of isolates, tests for immunity to P1 $\left(\operatorname{Imm}_{\mathrm{p} 1}\right)$ and for $\mathrm{P} 1$-specific restriction $[\operatorname{Res}(\mathrm{P} 1)]$ and modification $[\operatorname{Mod}(\mathrm{P} 1)]$ gave further support for the presence or absence of P1-determined functions. In general, killer producers contained these functions, and non-killer producers did not. However, a few exceptions to this rule were noticed (see footnotes).

\begin{tabular}{|c|c|c|c|c|c|c|c|c|}
\hline \multirow[b]{2}{*}{$\begin{array}{c}\text { Transducing } \\
\text { lysate }\end{array}$} & \multirow[b]{2}{*}{$\begin{array}{l}\text { Colony } \\
\text { size* }\end{array}$} & \multirow[b]{2}{*}{$\begin{array}{l}\mathrm{Cm}^{\prime} \text { trans- } \\
\text { ductants } \\
\text { tested }\end{array}$} & \multicolumn{4}{|c|}{ Transductant phenotypes } & \multicolumn{2}{|c|}{ P1 grown on transductants } \\
\hline & & & $\begin{array}{c}\mathrm{Cm}^{r} \mathrm{Sm}^{r} \\
\mathrm{Su}^{r} \mathrm{Hg}^{r} \\
(\mathrm{kp})\end{array}$ & $\begin{array}{c}\mathrm{Cm}^{r} \mathrm{Sm}^{r} \\
\mathrm{Su}^{r} \mathrm{Hg}^{\mathrm{s}} \\
(\mathrm{kp})\end{array}$ & $\begin{array}{c}\mathrm{Cm}^{\mathrm{r} S m^{\mathrm{s}}} \\
\mathrm{Su}^{\mathrm{s}} \mathrm{Hg}^{\mathrm{s}} \\
(\mathrm{kp})\end{array}$ & $\begin{array}{c}\mathrm{Cm}^{r} \mathrm{Sm}^{\mathrm{r}} \\
\mathrm{Su}^{\mathrm{s}} \mathrm{Hg}^{\mathrm{r}} \\
(\mathrm{kp})\end{array}$ & $\begin{array}{c}\text { No. of } \\
\text { P1 lysates } \\
\text { prepared }\end{array}$ & $\begin{array}{c}\text { Frequency of } \\
\mathrm{Cm}^{\mathrm{T}} \text { trans- } \\
\text { duction }\end{array}$ \\
\hline \multirow[t]{2}{*}{ P1-r-det81a } & Large & 15 & $\begin{array}{c}15 \\
(15)\end{array}$ & & & & & \\
\hline & Small & 12 & $\begin{array}{l}12 \\
(0)\end{array}$ & & & & 6 & All 6 low \\
\hline \multirow[t]{2}{*}{ P1-r-det $81 b$} & Large & 15 & $\begin{array}{c}14 \\
(14)\end{array}$ & $\begin{array}{l}1 \neq \\
(0)\end{array}$ & & & & \\
\hline & Small & 15 & $\begin{array}{c}9 \\
(0)\end{array}$ & $\begin{array}{c}5 \\
(0)\end{array}$ & $\begin{array}{c}1 \\
(0)\end{array}$ & & 7 & All 7 low \\
\hline \multirow[t]{2}{*}{ P1::r-det56 } & Large & 15 & $\begin{array}{c}14 \dagger \\
(13)\end{array}$ & & $\begin{array}{c}1 \\
(1)\end{array}$ & & $1 \dagger$ & High \\
\hline & Small & 14 & $\begin{array}{c}9 \\
(0)\end{array}$ & $\begin{array}{l}4 \S \\
(0)\end{array}$ & & $\begin{array}{c}1 \\
(0)\end{array}$ & 9 & All 9 low \\
\hline
\end{tabular}

\footnotetext{
* Most of the $\mathrm{Cm}^{r}$ transductants which originally appeared as small colonies carried the intact $\mathrm{r}$-det in the chromosome. In contrast, most $\mathrm{Cm}^{\mathrm{r}}$ transductants which appeared as large colonies were found to be P1-r-det and P1::r-det lysogens. The relative frequencies with which the two types of transductants are obtained and the characteristic difference in their colony size might depend both on the recipient strain and on the physiological condition used. We used in our experiments TG-medium (Iida \& Arber, 1977) and observed that this minimal medium offers better recovery of transductants than the rich medium used by Mise \& Nakaya (1977).

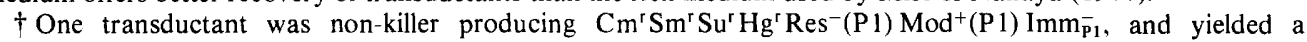
P1clts 162 lysate transducing $\mathrm{Cm}^{\mathrm{r}}$ at high frequency.

$\ddagger$ This transductant was non-killer producing $\mathrm{Cm}^{\mathrm{r}} \mathrm{Sm}^{r} \mathrm{Su}^{r} \mathrm{Hg}^{\mathrm{s}} \mathrm{Res}^{-}(\mathrm{P} 1) \mathrm{Mod}^{+}(\mathrm{P} 1) \mathrm{Imm}_{\mathrm{P} 1}^{+}$.

$\S$ One transductant was non-killer producing $\mathrm{Cm}^{r} \mathrm{Sm}^{r} \mathrm{Su}^{r} \mathrm{Hg}^{s} \mathrm{Res}^{-}(\mathrm{P} 1) \mathrm{Mod}^{-}(\mathrm{P} 1) \mathrm{Imm}_{\mathrm{Pl}}^{+}$.
}

\section{Chromosomal location of $r$-det elements in $\mathrm{Cm}^{r}$ transductants}

Genetic mapping experiments should confirm that the nonlysogenic $\mathrm{Cm}^{\mathrm{r}}$ transductants described in the preceding section carry the $\mathrm{r}$-det inserted in the chromosome. A number of $\mathrm{Cm}^{\mathrm{r}}$ transductants of WA3594 served as donors in matings with the multi-auxotrophic recipient $\mathrm{LC}$ 102. After selection for $l e u^{+}, \mathrm{proC}^{+}, \mathrm{purE}^{+}, \operatorname{trp}^{+}, \mathrm{his}^{+}, \operatorname{argG}^{+}$or metA $^{+}$ recombinants, linkage of these characters with $\mathrm{Cm}^{\mathrm{r}}$ was determined. The results of three representative experiments are shown in Table 3. Disregarding individual fluctuations, the degree of linkage between $\mathrm{Cm}^{\mathrm{r}}$ and chromosomal characters of each donor strain changed from low to high at a different distance measured clockwise from the $\mathrm{HfrH}$ origin of transfer. This suggested that the r-det element was carried at different chromosomal sites in the transductants studied. Determination of the time of entry of the $\mathrm{Cm}^{\mathrm{r}}$ character supported these interpretations. The integration of a $\mathrm{Cm}^{r}$ determinant into the bacterial chromosome had already been reported by lyobe et al. (1970).

Since the three auxotrophic strains WA3573, WA3574 and WA3575 are $\mathrm{F}^{-}$, confirmation of the chromosomal location of their $\mathrm{r}$-det was investigated by co-mobilization of the chromosome (Adelberg \& Burns, 1960) with the conjugative plasmid R100-1. This plasmid 
Table 3. Location of the r-det in the chromosome of WA3594 derivatives

(a) $\mathrm{HfrH}$ donor strains (point of origin at map coordinate $97 \mathrm{~min}$, clockwise transfer of chromosome) were conjugated with the multiauxotrophic recipient strain LC102 for $120 \mathrm{~min}$. Streptomycin $\left(200 \mu \mathrm{g} \mathrm{ml}^{-1}\right)$ resistance ( $\left.r p s L, 72 \mathrm{~min}\right)$ served for counterselection in the separate isolation of transconjugants for each of the selective characters listed. Transconjugants were then replicated on to $\mathrm{Cm}$-containing plates to determine the degree (percentage) of linkage of $\mathrm{r}$-det with the selected character. Chromosomal map coordinates (Bachmann et al., 1976) are given in parenthesis.

(b) In interrupted matings the time of entry of $\mathrm{Cm}^{\mathrm{r}}$ (i.e. r-det) was determined relative to the standard times of entry (i.e. map coordinates) of the characters listed in (a).

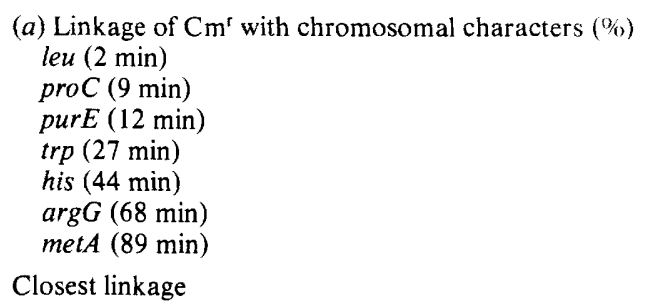

(b) Approx. time of entry of $\mathrm{Cm}^{\mathrm{r}}$ (chromosomal map units)

$\overbrace{\text { WA3767 }}^{\text {HfrH donor strain }}$

$\begin{array}{ccc}1 & 62 & 16 \\ 4 & 47 & 73 \\ 8 & 27 & 42 \\ 4 & 13 & 15 \\ 5 & 9 & 13 \\ 15 & 17 & 9 \\ 34 & 10 & 2 \\ \text { metA }(89 \mathrm{~min}) & \text { leu }(2 \mathrm{~min}) & \text { proc }(9 \mathrm{~min}) \\ 75 \mathrm{~min} & 4 \mathrm{~min} & 11 \mathrm{~min}\end{array}$

Table 4. Location and orientation of the r-det in the chromosome of three auxotrophic $\mathrm{Cm}^{r}$ derivatives of $W 3110(\lambda)$

Matings based on mobilization of the donor chromosome with R 100-1 were performed as described in Methods, using rifampicin $\left(80 \mu \mathrm{g} \mathrm{m} l^{-1}\right)$ resistance (rpoB $\left.{ }^{+}, 89 \mathrm{~min}\right)$ for counterselection. The gradient of transmission of donor characters (map coordinates given in parenthesis) to the recipient strain $\mathrm{CH} 104$ is seen from the frequency of prototrophic recombinants per donor bacterium. The direction of transfer of the chromosome (cw, clockwise; ccw, counterclockwise) identifies the orientation of the $r$-det carried in the chromosome.

\begin{tabular}{|c|c|c|c|c|c|c|c|c|}
\hline \multicolumn{2}{|c|}{ Plasmid transconjugant } & \multicolumn{6}{|c|}{$\begin{array}{l}\text { Gradient of transmission for chromosomal markers } \\
\left(10^{7} \times \text { frequency of prototrophic recombinants }\right)\end{array}$} & \multirow[b]{2}{*}{$\begin{array}{l}\text { Direction of } \\
\text { transfer }\end{array}$} \\
\hline $\begin{array}{c}\text { Strain } \\
\text { designation }\end{array}$ & $\begin{array}{l}\text { Relevant } \\
\text { character }\end{array}$ & $\begin{array}{c}l e u \\
(2 \mathrm{~min})\end{array}$ & $\begin{array}{l}\text { proC } \\
(9 \min )\end{array}$ & $\begin{array}{c}\operatorname{trp} \\
(27 \mathrm{~min})\end{array}$ & $\begin{array}{c}\text { his } \\
(44 \mathrm{~min})\end{array}$ & $\underset{(68 \mathrm{~min})}{\arg G}$ & $\begin{array}{c}i l v \\
(83 \mathrm{~min})\end{array}$ & \\
\hline WA3573(R 100-1) & $i l v$ & 400 & 200 & 82 & 20 & $5 \cdot 2$ & - & $\mathrm{cw}$ \\
\hline WA3574(R 100-1) & his & 51 & 35 & 2800 & - & 11 & 16 & $\mathrm{ccw}$ \\
\hline WA3575(R100-1) & $*$ & 1000 & 840 & 84 & 15 & 4.8 & 5.4 & $\mathrm{cw}$ \\
\hline W31 10(ג)(R100-1) & + & 2.7 & $7 \cdot 5$ & 70 & 24 & 15 & 10 & - \\
\hline
\end{tabular}

carries the r-det at a known site and in a known orientation with respect to the transfer origin, $\mathrm{Hg}^{\mathrm{r}}$ being the first and $\mathrm{Cm}^{\mathrm{r}}$ the last of the resistance determinants to be transferred (Legrand et al., 1979). Since chromosome mobilization depends mainly on reciprocal recombination within the homologous $r$-det elements of the conjugative plasmid and of the chromosome, an analysis of the gradient of transmission of chromosomal markers in mobilization experiments allows the determination both of the map position of the r-det, and of its orientation. Chromosomal markers proximal to the $\mathrm{Cm}$ end of the integrated $\mathrm{r}$-det are expected to be transferred early, and thus more frequently, in conjugation; markers proximal to the $\mathrm{Hg}$ end of $r$-det will be transferred last, and thus less frequently. The results in Table 4 reflect a gradient of transmission for chromosomal characters as expected for unidirectional 

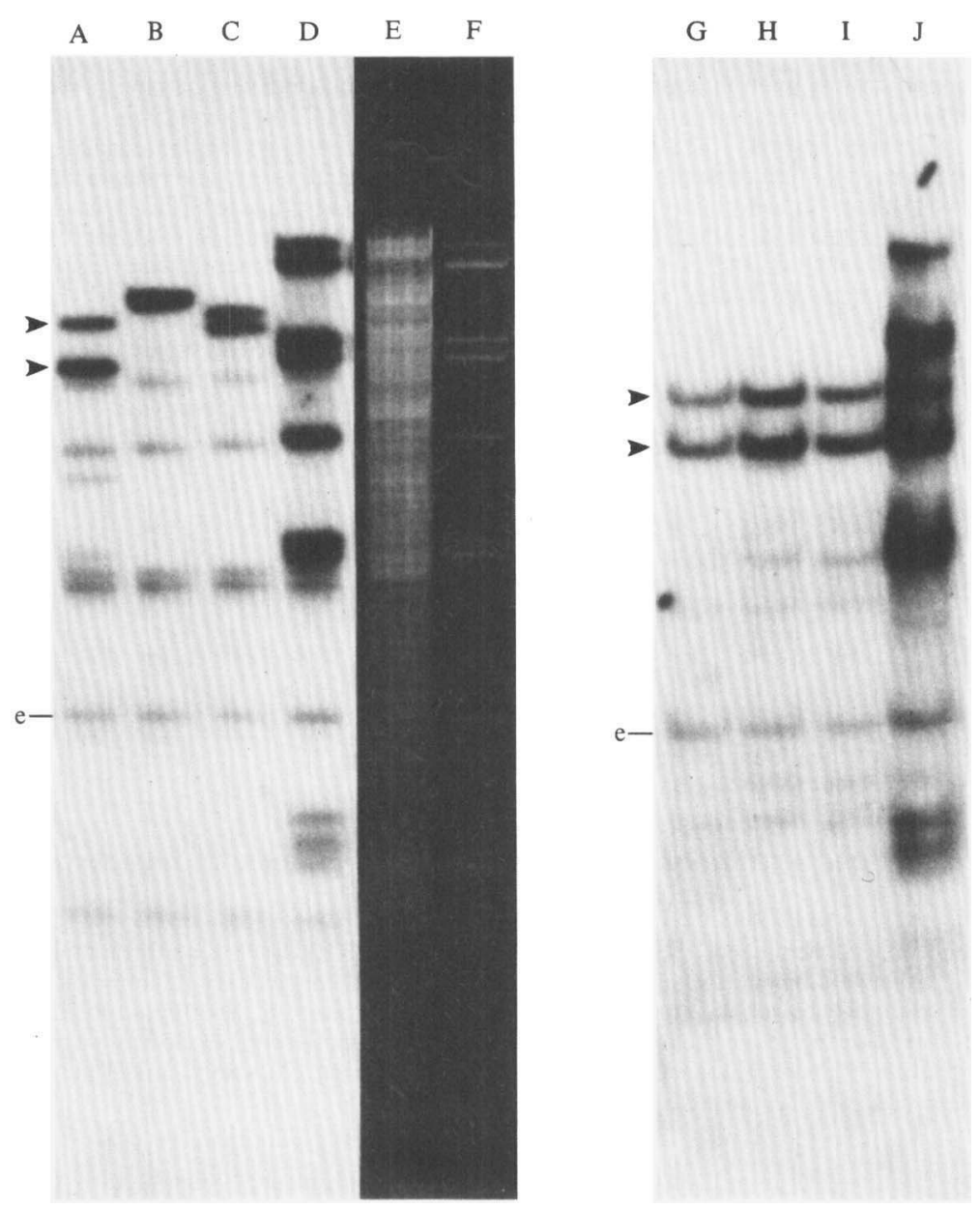

Fig. 1. DNA-DNA hybridization between radioactive P1::r-det56 DNA and DNA from bacteria carrying $\mathrm{r}$-det integrated in their chromosome. Hybridization patterns of ${ }^{32} \mathrm{P}$-labelled P1::r-det56 with the chromosomal and plasmid DNA cleaved by either $B g I I I(A-D)$ or $B g l I I+P s t I(G-J)$ are shown. A and G, DNA from WA3767; B and H, DNA from WA3768; C and I, DNA from WA3769; D and J, DNA from WA3594 lysogenic for P1-r-det81. Patterns of $B g l$ II fragments of DNA from WA3594 lysogenic for P1-r-det81 (E) and of phage P1-r-det81 DNA (F) are also shown. The chromosomal DNA was digested with the restriction enzymes and the resulting fragments were separated by $0.8 \%$ agarose gel electrophoresis, transferred to a nitrocellulose sheet and hybridized with ${ }^{32} \mathrm{P}$-labelled P1::r-det56 DNA as described in Methods. Band e is the internal BglII fragment of r-det (see Fig. 3). The arrows point to the pair of end fragments of $r$-det carried in WA3767 (slots A and G). The corresponding pair of $B g l \mathrm{II}$ fragments from WA3768 is seen in slot B as a double band. In the $B g / \mathrm{II}$ digest of WA 3769 the two corresponding fragments form the two largest fragments (slot C). See text for a discussion of the origin of the remaining hybridization bands.

mobilization of the bacterial chromosome. The data shown for strain WA3573 are in agreement with the notion that $\mathrm{r}$-det is carried at map coordinate 83 (ilv) and they indicate that the r-det is orientated clockwise in the order $\mathrm{SuSmCm}$ on the E. coli chromosome map. In strain WA3574 the r-det is carried at map coordinate 44 ( his) and in the orientation $\mathrm{CmSmSuHg}$ relative to the clockwise order of the chromosomal characters. Strain WA3575 may have its $r$-det insertion causing an unidentified auxotrophic mutation between map coordinates 83 and 2 , and in the orientation $\mathrm{HgSuSmCm}$ relative to the clockwise order of the chromosomal characters. 

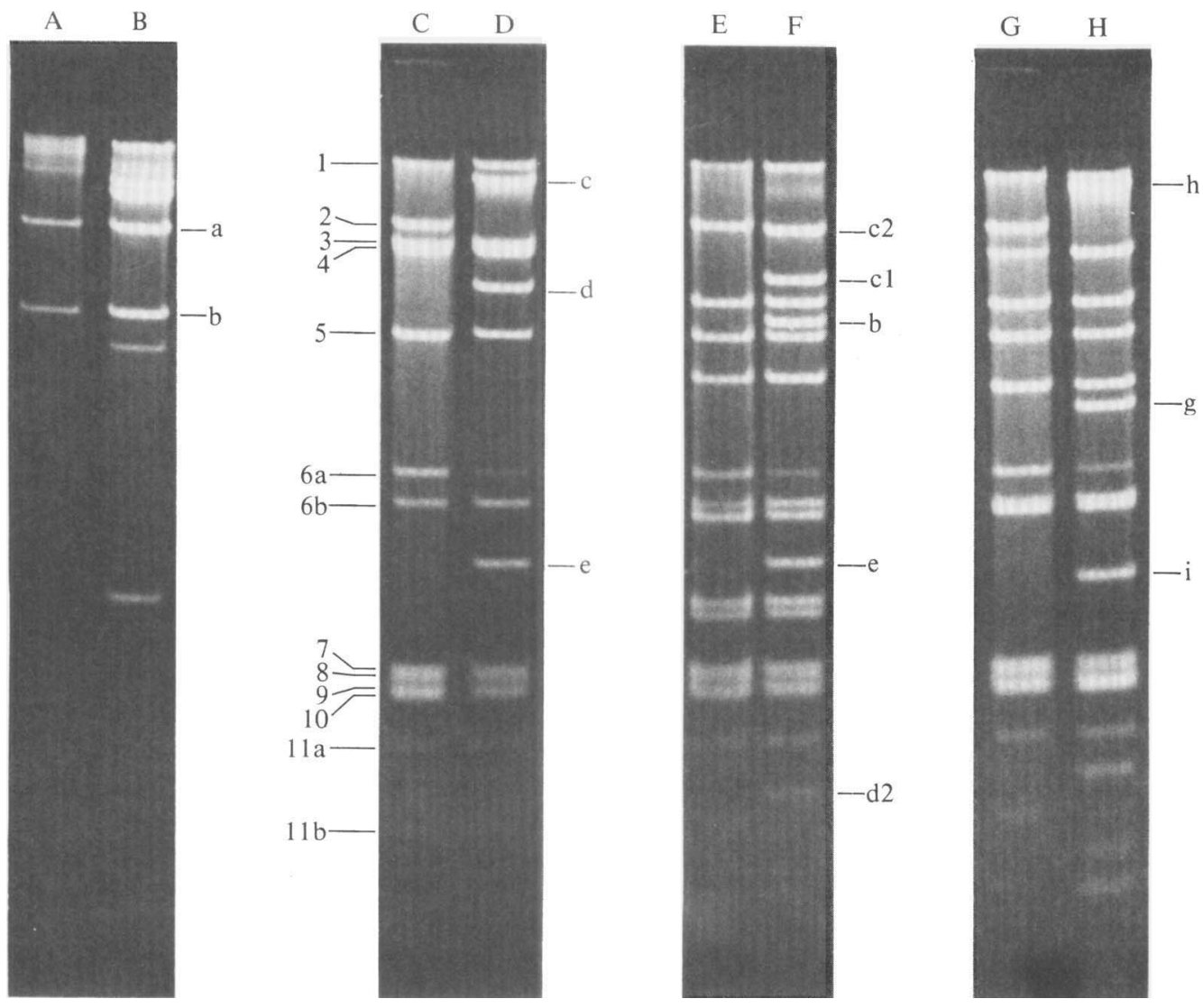

Fig. 2. Electrophoresis patterns of phage DNA after treatment with restriction endonucleases. A, P1-r-det81 DNA digested by PstI; B, P7::r-det209 DNA digested by PstI; C, P7 DNA digested by $B g l$ II [numbering of bands is according to lida \& Arber (1979)]; D, P7::r-det209 DNA digested by BglII; E, P7 DNA digested by PstI + BglII; F, P7::r-det209 DNA digested by PstI + BglII; G, P7 DNA digested by $B g I I I+H i n d I I I ; H, P 7:: r-d e t 209$ DNA digested by BgIII + HindIII. Letter identification of bands is arbitrary and corresponds to the labelling in Fig. 3. Electrophoresis was carried out in $0.7 \%$ agarose.

DNA-DNA hybridization experiments provide evidence for the presence of the complete r-det in the chromosomes of $\mathrm{Cm}^{r}$ transductants

Specific hybridization between DNA fragments prepared by restriction cleavage can provide information on the origin and amount of DNA carried in the chromosomes of $\mathrm{Cm}^{\mathrm{r}}$ transductants. For this purpose DNA from P1 : : r-det56 was ${ }^{32} \mathrm{P}$-labelled by nick translation. This probe and nonradioactive chromosomal DNA digested with BgIII restriction endonuclease were used in a Southern hybridization experiment (Southern, 1975) (Fig. 1, A-D). Since the r-det used contains two BglII sites (see Fig. 3), only one BglII fragment of constant size (labelled e) is expected to be seen in $B g l$ II digests of chromosomes from transductants carrying an $r$-det at different locations. The two end fragments will probably be of variable size for independent transductants. This is indeed what was found for the three strains studied (Fig. 1). The remaining hybridizations most probably involved IS 1 and the $1.25 \mathrm{~kb}$ IS element, now called IS30, carried in the r-det used, since both are also carried in the $E$. coli chromosome (Arber et al., 1978). Strain WA3767 (Fig. 1, A, G) differs in this respect from the other two strains studied. 


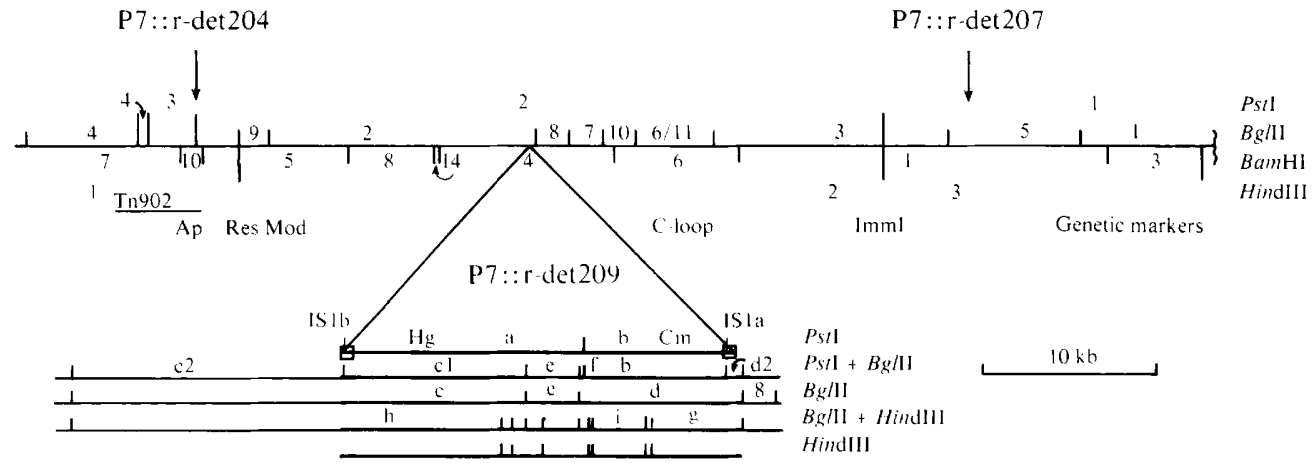

Fig. 3. Location and orientation of $\mathrm{r}$-det in three independent P7::r-det derivatives. The PstI, Bg/II, BamHI and HindIII restriction maps of the relevant sector of the phage P7 genome are from lida \& Arber (1979). The genetic markers shown refer to the ampicillin resistance determinant (Ap) which is carried on Tn902, the P1-specific restriction (Res) and modification (Mod) determinants, the invertible segment (C-loop) and the immunity determinant (ImmI) (see Yarmolinsky, 1977). The bottom part of the figure shows the site and the orientation of the r-det insertion (heavy lines) carried by P7::r-det 209, as determined from the results shown in Fig. 2. Arbitrary labelling is as in Fig. 2. The top part of the figure indicates the sites of the r-det insertions carried by P7::r-det204 and P7::r-det207. The orientation of these $r$-det insertions is the same as in P7::r-det209.

Digestion of any DNA containing an intact r-det element with both $B g / \mathrm{II}$ and $P s t \mathrm{I}$ should yield four unique fragments, $c 1, e, f$ and $b$ (Fig. 3), independently of where the $r$-det is inserted. Fig. 1 identifies three of these fragments in digests of a P1-r-det81 lysogenic derivative of WA3594 and of the three independent transductants (WA3767, WA3768 and WA3769) already discussed. Fragment $\mathrm{f}$ is very small and therefore not seen on the gel. These results show that $\mathrm{r}$-det is carried intact in each of the chromosomes analysed. In contrast, no evidence was found that these transductants also carried measurable amounts of P1 DNA in their chromosomes. These conclusions were supported by the hybridization patterns of the chromosomal DNA digested with BamHI (results not shown). Experiments with several other strains, including WA3574 and WA3575, gave analogous results (not shown). These results confirm the genetic evidence that suggests that $r$-det translocated as a unit from $\mathrm{P} 1$ DNA to the bacterial chromosome.

\section{Transposition of $r$-det from the host chromosome to the phage P7 genome}

To verify that $r$-det can transpose further from its integration site on the chromosome, we tried to recover it on the phage P7 genome. Phage P7 shows extended homology with P1, including the Res(P1) Mod(P1) region, but it does not carry IS1 (Yun \& Vapnek, 1977; Iida \& Arber, 1979). Cells lysogenic for P7::r-det were isolated by the enrichment procedure described in Methods. Out of $12 \mathrm{Cm}^{r} \mathrm{Sm}^{r} \mathrm{Su}^{r} \mathrm{Hg}^{r}$ transductants which gave high-frequency transducing lysates for $\mathrm{Cm}^{r}, \mathrm{Sm}^{\mathrm{r}}, \mathrm{Su}^{\mathrm{r}}$ and $\mathrm{Hg}^{\mathrm{r}}, 11$ showed $\mathrm{Res}^{+}(\mathrm{P} 1)$ phenotype. Of these, three strains lysogenic for P7::r-det204, 207 and 209 (Table 1) were chosen for further studies, and we demonstrated by restriction cleavage analysis that they carried P7::r-det prophages. The restriction cleavage maps of these $\mathrm{P} 7:: \mathrm{r}$-det phage genomes were constructed by comparing their cleavage patterns with those of P7 DNA and r-det (Arber et al., 1978; Iida \& Arber, 1979; Iida \& Arber, 1980; Iida, 1980). We will describe here in detail only the study of P7::r-det209 DNA (Figs 2 and 3).

In the $B g /$ II digestion of P7::r-det209 DNA, two hybrid fragments, c and d, appeared together with the internal $B g l \mathrm{II}$ fragment e of r-det, while the $B g / \mathrm{II}-2$ fragment of P7 was missing (Fig. 2, D). In the BglII + PstI digest, two end fragments, $\mathrm{c} 1$ and $\mathrm{b}$, of $\mathrm{r}$-det and two fragments, $\mathrm{c} 2$ and $\mathrm{d} 2$, containing the material from $B g / \mathrm{ll}-2$ and $\mathrm{P} 7$ appeared instead of hybrid $B g l$ II fragments $\mathrm{c}$ and d (Fig. 2, F). The presence of the small fragment $\mathrm{f}$ (not seen in Fig. 2) 
derived from r-det was confirmed by electrophoresis in acrylamide agarose (results not shown). As mentioned in the preceding section, the appearance of BglII + PstI fragments cl and $b$ indicates that the r-det carried on P7::r-det209 has no deletion. Since the r-det was integrated in the Bam $\mathrm{HI}-4$ fragment of $\mathrm{P} 7$ (results not shown), the small $\mathrm{d} 2$ hybrid fragment between r-det and $B g l I I-2$ of $\mathbf{P} 7$ must lie adjacent to $B g l I I-8$, and the long hybrid fragment $\mathrm{c} 2$ adjacent to $B g I I I-9$. The resulting orientation of $\mathrm{r}$-det within the $B g I I I-2$ fragment of P7 DNA is shown in Fig. 3. It was independently confirmed with $B g / I I+H i n d l I I$ double digestion (Figs 2 and 3). The HindIII + PstI fragment derived from the end of $\mathrm{r}$-det containing the cat gene is known to be $4.7 \mathrm{~kb}$ in size, whereas the other end fragment containing the mer gene is $9.2 \mathrm{~kb}$ (Arber et al., 1978; Iida \& Arber, 1980; Iida, 1980). Since the smaller hybrid fragment $\mathrm{g}$ of the $B g I I I+H i n d I I I$ digest, containing material of both $\mathrm{r}$-det and fragment $B g l \mathrm{II}-2$ of $\mathrm{P} 7$, is only $5.7 \mathrm{~kb}$, it must include the $\mathrm{Cm}^{\mathrm{r}}$ region of r-det and the $1 \mathrm{~kb} P s t \mathrm{I}+B g l \mathrm{II}$ fragment d2. Thus, the longer $B g l \mathrm{II}+H i n d I I I$ hybrid fragment h consists of the $\mathrm{Hg}^{\mathrm{r}}$ region of r-det and the major part of $B g$ lII- 2 of P7.

We conclude from these results that P7::r-det209 carries the intact r-det flanked by two IS 1 elements at about $0.4 \mathrm{~kb}$ to the left of the $B g l \mathrm{II}$ cleavage site located between $B g / \mathrm{II}-2$ and $B g l I I-8$, and in the orientation shown in Fig. 3. This conclusion found further support from $B a m \mathrm{HI}, B a m \mathrm{HI}+P s t \mathrm{I}, E c o \mathrm{RI}$ and EcoRI + PstI restriction cleavage patterns and by Southern DNA-DNA hybridization patterns of $B a m \mathrm{HI}, B a m \mathrm{HI}+P s t \mathrm{I}, B g l \mathrm{II}+P s t \mathrm{I}, E c o \mathrm{RI}$ and $E c o R I+P s t I$ fragments with a ${ }^{32}$ P-labelled IS 1 probe (results not shown).

From a similar analysis, we conclude that DNA of phage P7::r-det204, which does not confer $\mathrm{Ap}^{\mathrm{r}}$, carries the intact $\mathrm{r}$-det at about $0.1 \mathrm{~kb}$ to the right of the Pst I site between fragments Pst I-2 and Pst I-3, with the cat gene of r-det to the right side on the P7 genetic map. This insertion site is in the C-terminal part of the bla gene ( $\mathrm{Ap}^{\mathrm{r}}$ determinant) of the Tn3 related transposon Tn902 carried by P7. From WA921(P7::r-det204), $\mathrm{Ap}^{\mathrm{r}} \mathrm{Cm}^{\mathrm{s}} \mathrm{Sm}^{\mathrm{s}} \mathrm{Su}^{\mathrm{s}} \mathrm{Hg}^{\mathrm{s}}$ colonies appeared with a frequency of $10^{-10}$. These carry a prophage whose restriction cleavage patterns are indistinguishable from those of P7 DNA. This indicates that the revertant genomes resulted from precise excision of $r$-det.

Phage P7::r-det207 was shown to carry the intact r-det within segment $B g / I I-5$ situated to the right of the immunity region of $\mathrm{P} 7$. No structural difference was seen between the Res(P1) regions of $\mathrm{P} 7:: \mathrm{r}-\operatorname{det} 207$ and $\mathrm{P} 7$, which suggests that the $\mathrm{Res}^{-}(\mathrm{P} 1) \mathrm{Mod}^{+}(\mathrm{P} 1)$ phenotype of $\mathrm{P} 7:: \mathrm{r}$-det207 is probably due to a mutation in the $\operatorname{res}(\mathrm{P} 1)$ gene independent of the insertion of $r$-det. The orientation of $r$-det in P7::r-det207 is the same as in the other two P7 derivatives studied here.

In a similar study, we obtained the transposition of the intact r-det from WA3574 his : : r-det to the P1 genome at a site outside of its resident IS 1 element (results not shown).

\section{DIS C US SION}

In previous papers (lida \& Arber, 1977, 1980) we showed evidence for the transposition of the r-determinant element of NR1 to the genome of bacteriophage P1. In one of two carefully studied derivatives, the resulting phage genome carried its acquired r-det, flanked by two IS 1 elements, at a site not previously carrying an IS1 element. In the other P1 derivative, however, the r-det, again flanked by two IS1 elements, was carried at the site of the resident IS 1 of $\mathrm{P} 1$. Both of these $\mathrm{P} 1$ phages served in this paper for the transduction of r-det to E. coli K 12 recipient bacteria. Many of the drug-resistant transductants carried the entire $r$-det element, but no P1 sequences. In each isolate, the $\mathrm{r}$-det was integrated at a different site of the chromosome. Upon growth of phage P7 in such r-det transductants, the r-det element sometimes transposed to the $\mathbf{P} 7$ genome, and our studies revealed the presence of the entire $\mathrm{r}$-det at a different location on the $\mathrm{P} 7$ genome in each derivative studied.

Campbell et al. (1977) defined transposable elements as DNA segments which can insert into several sites in a genome. Our results clearly show that $r$-det falls under this definition. 
Since IS1-flanked $r$-det contains a number of selectable antibiotic resistance genes which obviously are unrelated to insertion functions (Alton \& Vapnek, 1979; Iida et al., 1980 b; Marcoli et al., 1980; Reif, 1980; Rosner \& Guyer, 1980), it corresponds to the definition of a transposon. We will thus call the r-det studied here Tn2671 (Table 1).

Recently published models suggest that transposable elements undergo duplication in the process of their transposition to a new insertion site (Grindley \& Sherratt, 1978; Shapiro, 1979; Arthur \& Sherratt, 1979). We shall therefore discuss whether this is also likely to occur for Tn2671. Since r-det is flanked by two IS1 elements carried in the same orientation, and IS 1 itself is a transposable element, any of the following alternative possibilities may account for the transposition of $\mathrm{r}$-det. (1) The entire Tn2671 could undergo duplication, and a daughter copy could integrate at a new target site. (2) The flanking IS1 elements could serve in reciprocal recombination to sort out the $r$-det from its donor DNA molecule, and transpositional duplication of only one IS 1 element could result in the cointegration of a target DNA molecule with the $\mathrm{r}$-det sequences. In general, IS1-mediated transpositional cointegration and subsequent reciprocal recombination at IS 1 could also produce the same structure. (3) The whole translocation process might depend only on reciprocal recombination between IS1 sequences, if an IS1 element already carried in the target DNA molecule served as site for the insertion. In this mechanism no local DNA replication might be involved. Mechanism (3) is likely to have led to the production of phage P1-r-det81 in which $\mathrm{r}$-det is carried at the resident IS1 of P1. The same mechanism may also have served in the translocation of $\mathrm{r}$-det to some of the chromosomal sites. However, it cannot explain the formation of P1::r-det56 or of any of the P7::r-det derivatives, since P7 DNA carries no IS1. These derivatives, as well as some of the chromosomal integrations, could be formed by either mechanism (1) or mechanism (2). However, an alternative mechanism (4) might also explain the formation of these transposition derivatives: an IS1 could have first transposed from the $E$. coli chromosome to the P7 genome, and then could have served for the translocation of $r$-det, based on reciprocal recombination according to mechanism (3).

Although any of these possible mechanisms can probably be used, they may serve at different frequencies. When the $E$. coli chromosome is a target, for example, we expect that the resident IS 1 elements of the chromosome may frequently be chosen as sites of integration of r-det. New sites on the $E$. coli chromosome may be used considerably less frequently for the insertion of $r$-det. This may explain why we found only three auxotrophic mutants among $5000 \mathrm{Cm}^{\mathrm{r}}$ transductants, a frequency about 20 -fold lower than what one would expect in comparison with Tn5 and Tn 10 mutagenesis (Berg, 1977; Kleckner et al., 1975).

The mechanisms involving reciprocal recombination at IS1 elements are expected to depend on recA functions (Silver et al., 1980; S. Iida, unpublished observation). However, some reciprocal recombination between ISI elements was also observed in $\operatorname{rec} A^{-}$bacteria (MacHattie \& Jackowski, 1977; Shapiro \& MacHattie, 1978). For example, P1Cm202, the formation of which must have involved the reciprocal recombination of the IS 1 of P1 and an IS1 of NR1, was isolated in rec $A^{-}$bacteria (Iida \& Arber, 1977; Arber et al., 1978; Iida \& Arber, 1980). In addition, both IS1-mediated cointegration and transposition of IS1 have been observed in the $r e c A^{-}$condition (Shapiro \& MacHattie, 1978; Iida \& Arber, 1980; Ohtsubo et al., 1980; Read et al., 1980). For these reasons we do not think that experiments with $\mathrm{rec} \mathrm{A}^{-}$bacteria could unequivocally demonstrate the use of a single one of the four mechanisms discussed above for the transposition of $r$-det.

The P1::r-det prophages used as starting material in our experiments are 'oversized' genomes of about $113 \mathrm{~kb}$, while only about $100 \mathrm{~kb}$ of genetic material are packaged into mature P1 phage particles (Iida \& Arber, 1980). Because of the resulting lack of terminal redundancy, injected DNA from single phage particles cannot be circularized to re-form P1::r-det plasmids. In contrast, recombination between the IS 1 elements flanking the $r$-det can result in the formation of circular r-det, which is unable to replicate autonomously in $E$. coli K12 (Lane et al., 1979). The subsequent integration of r-det into the chromosome (or 
into another replicon) by mechanism (2), (3) or (4) may lead to the formation of a stable transductant. This process may be more frequent than transposition of Tn2671 according to mechanism (1) in our experimental conditions.

Evidence for the occasional use of mechanism (1), involving the duplication of the full length of Tn2671, was recently provided by the study of a phage P7 derivative. Its genome carries two copies of Tn2671 as inverted repeats, and the part of the P7 genome between the two inserted copies of Tn2671 is inverted with respect to that of wild-type P7 (C. Hänni, J. Meyer and S. Iida, unpublished observation). By analogy with IS 1-mediated inversion (Cornelis \& Saedler, 1980; Iida et al., 1980a), we interpret this structure to have resulted from the transposition of the entire r-det from one location to another on the same P7 genome.

In conclusion, we consider it as a matter of definition whether or not $r$-det can be classified as transposon. The same arguments apply to any other transposon flanked by directly repeated IS1 elements, including the well-studied Tn9 (MacHattie \& Jackowski, 1977; Arber et al., 1978). Not considering mechanistic aspects, these elements clearly are transposons. For matters of ecological and evolutionary relevance, knowledge on the molecular mechanism used in any single transposition event may appear less important than the demonstration that a block of genes can translocate under natural conditions and with remarkable genetic stability from one plasmid to another, then on to the $E$. coli chromosome, and then on to a third plasmid. This confirms the existence of natural mechanisms for spreading drug resistance genes from one genome to another. These mechanisms making use of viral and conjugative plasmid genomes as natural vectors are obviously not specific for drug resistance genes, but probably reflect mechanisms generally used to exchange genome segments between different species. Although these exchanges occur at low frequencies, they certainly present important factors in evolution.

We wish to thank Elisabeth Wittwer and Solveig Schrickel for their technical assistance, Thomas A. Bickle for supplying restriction enzymes, and Jürg Meyer for discussions and reading the manuscript. This work was supported by the Swiss National Science Foundation.

\section{REFERENCES}

Adelberg, E. A. \& Burns, S. N. (1960). Genetic variations in the sex factor of E. coli. Journal of Bacteriology 79, 321-330.

Alton, N. K. \& VApNeK, D. (1979). Nucleotide sequence analysis of the chloramphenicol resistance transposon Tn9. Nature, London 282, 864-869.

Arber, W., Iida, S., JütTe, H., Caspers, P., Meyer. J. \& HÄNNI, C. (1978). Rearrangements of genetic material in Escherichia coli as observed on the bacteriophage P1 plasmid. Cold Spring Harbor Symposia on Quantitative Biology 43, 1197-1208.

Arthur, A. \& Sherratt, D. (1979). Dissection of the transposition process: a transposon-encoded sitespecific recombination system. Molecular and General Genetics 175, 267-274.

Bachmann, B. J., Low, K. B. \& TAYLoR, A. L. (1976). Recalibrated linkage map of Escherichia coli. Bacteriological Reviews 40, 116-167.

BERG, D. E. (1977). Insertion and excision of the transposable kanamycin resistance determinant Tn5. In DNA Insertion Elements, Plasmids, and Episomes, pp. 205-212. Edited by A. I. Bukhari, J. A. Shapiro \& S. L. Adhya. New York: Cold Spring Harbor Laboratory.
BotsteIN, D. \& KLECKNER, N. (1977). Transposition and illegitimate recombination by the tetracycline resistance element Tn10. In DNA Insertion Elements, Plasmids, and Episomes, pp. 185-203. Edited by A. I. Bukhari, J. A. Shapiro \& S. L. Adhya. New York: Cold Spring Harbor Laboratory.

Brevet, J., Kopecko, D. J., Nisen, P. \& Cohen, S. N. (1977). Promotion of insertions and deletions by translocating segments of DNA carrying antibiotic resistance genes. In DNA Insertion Elements, Plasmids, and Episomes, pp. 169-178. Edited by A. I. Bukhari, J. A. Shapiro \& S. L. Adhya. New York: Cold Spring Harbor Laboratory.

Camprell, A., Berg, D., Botstein, D., Lederberg, E., Novick, P., Starlinger, P. \& Szybalski, W. (1977). Nomenclature of transposable elements in prokaryotes. In DNA Insertion Elements, Plasmids, and Episomes, pp. 15-22. Edited by A. I. Bukhari, J. A. Shapiro \& S. L. Adhya. New York: Cold Spring Harbor Laboratory.

Cornelis, G. \& SAedler, H. (1980). Deletions and an inversion induced by a resident IS1 of the lactose transposon Tn951. Molecular and General Genetics $178,367-374$. 
Egawa, R. \& Hirota, Y. (1962). Inhibition of fertility by multiple drug resistance (R) factor in Escherichia coli K 12. Japanese Journal of Genetics 37, 66-69.

Grindley, N. D. F. \& Sherratt, D. J. (1978). Sequence analysis at IS1 insertion sites: models for transposition. Cold Spring Harbor Symposia on Quantitative Biology 43, 1257-1261.

HefFron, F., Rubens, C. \& Falkow, S. (1977). Transposition of a plasmid DNA sequence which mediates ampicillin resistance: general description and epidemiological considerations. In DNA Insertion Elements, Plasmids, and Episomes, pp. 151160. Edited by A. I. Bukhari, J. A. Shapiro \& S. L. Adhya. New York: Cold Spring Harbor Laboratory.

Hu, S., Ohtsubo, E., Davidson, N. \& Saedler, H. (1975). Electron microscope heteroduplex studies of sequence relations among bacterial plasmids: identification and mapping of the insertion sequences IS 1 and IS2 in F and R plasmids. Journal of Bacterio$\log y$ 122, 764-775.

IIDA, S. (1980). A cointegrate of the bacteriophage PI genome and the conjugative $R$ plasmid $R 100$. Plasmid 3, 278-290.

IIDA, S. \& ARBER, W. (1977). Plaque forming specialized transducing phage P1: isolation of $\mathrm{P} 1 \mathrm{CmSmSu}$, a precursor of $\mathrm{P} 1 \mathrm{Cm}$. Molecular and General Genetics 153, 259-269.

IIDA, S. \& ARBER, W. (1979). Multiple physical differences in the genome structure of functionally related bacteriophages $\mathrm{P} 1$ and $\mathrm{P} 7$. Molecular and General Genetics 173, 249-261.

IIDA, S. \& ARBER, W. (1980). On the role of IS 1 in the formation of hybrids between the bacteriophage P1 and the R plasmid NR1. Molecular and General Genetics 177, 261-270.

IIDA, S., Meyer, J. \& ARbER, W. (1980a). IS1 mediated inversion observed in phage $\mathrm{P} / \mathrm{CmTcl}$ DNA. Experientia 36, 748.

IIDA, S., MEYER, J. \& ARBER, W. (1980 b). Genesis and natural history of IS-mediated transposons. Cold Spring Harbor Symposia on Quantitative Biology 45, 27-43.

Iyobe, S., Hashimoto, H. \& Mitsuhashi, S. (1970). Integration of chloramphenicol resistance genes of an $\mathbf{R}$ factor into various sites of an Escherichia coli chromosome. Japanese Journal of Microbiology 14, 463-471.

Kleckner, N., Chan, R. K., Tye, B.-K. \& Botstein, D. (1975). Mutagenesis by insertion of a drugresistance element carrying an inverted repetition. Journal of Molecular Biology 97, 561-575.

LANE, D. \& Chandler, M. (1977). Mapping of the drug resistance genes carried by the r-determinant of the R100-1 plasmid. Molecular and General Genetics 157, 17-23.

Lane, D., Chandler, M., Silver, L., Bruschi, A. \& CARO, L. (1979). The construction and replication properties of hybrid plasmids composed of the r-determinant of R100-1 and the plasmids pCR 1 or pSC201. Molecular and General Genetics 168. 337-340.

Legrand, P., Bouche, J.-P. \& Louarn, J.-M. (1979). Direction of deoxyribonucleic acid transfer and replication in a derivative of plasmid R 100-1. Journal of Bacteriology 140, 1105-1108.

Machattie, L. A. \& Jackowski, J. B. (1977). Physical structure and deletion effects of the chloramphenicol resistance element $\operatorname{Tn} 9$ in phage lambda. In DNA Insertion Elements, Plasmids, and Episomes, pp. 219-228. Edited by A. I. Bukhari, J. A. Shapiro \& S. L. Adhya. New York: Cold Spring Harbor Laboratory.

MarColi, R., IIDA, S. \& Bickle, T. A. (1980). The DNA sequence of an IS1-flanked transposon coding for resistance to chloramphenicol and fusidic acid. FEBS Letters 110, 11-14.

MEYER, J. \& IIDA, S. (1979). Amplification of chloramphenicol resistance transposons carried by phage $\mathrm{P} 1 \mathrm{Cm}$ in Escherichia coli. Molecular and General Genetics 176, 209-219.

Mikı, T., Easton, M. \& Rownd, R. (1978). Mapping of the resistance genes of the $\mathrm{R}$ plasmid NR 1 . Molecular and General Genetics 158, 217-224.

Miller, J. H. (1972). Experiments in Molecular Genetics. New York: Cold Spring Harbor Laboratory.

Mise, K. \& NakAyA, R. (1977). Transduction of R plasmids by bacteriophages $\mathrm{P} 1$ and $\mathrm{P} 22$ : distinction between generalized and specialized transduction. Molecular and General Genetics 157, 131-138.

Novick, R. P., Clowes, R. C., Cohen, S. N., Curtiss, R., III, DatTa, N. \& Falkow, S. (1976). Uniform nomenclature for bacterial plasmids: a proposal. Bacteriological Reviews 40, 168-189.

Ohtsubo, E., Zenilman, M. \& Ohtsubo, H. (1980). Plasmids containing insertion elements are potential transposons. Proceedings of the National Academy of Sciences of the United States of America 77, $750-754$.

Ptashne, K. \& Cohen, S. N. (1975). Occurrence of insertion sequence (IS) regions on plasmid deoxyribonucleic acid as direct and inverted nucleotide sequence duplications. Journal of Bacteriology 122 , 776-781.

Read, H. A., Sarma, S. D. \& Jaskunas, S. R. (1980). Fate of donor insertion sequence IS 1 during transposition. Proceedings of the National Academy of Sciences of the United States of America 77, 2514-2518.

ReIF, H. J. (1980). Genetic evidence for absence of transposition functions from the internal part of Tn981, a relative of $\operatorname{Tn} 9$. Molecular and General Genetics 177, 667-674.

Rosner, J. L. \& GUyer, M. S. (1980). Transposition of IS 1 - $\lambda$ BIO-ISI from a bacteriophage $\lambda$ derivative carrying the IS1-cat-IS1 transposon (Tn9). Molecular and General Genetics 178, 111-120.

ScotT, J. R. (1968). Genetic studies on bacteriophage P1. Virology 36, 564-574.

Shapiro, J. A. (1979). Molecular model for the transposition and replication of bacteriophage $\mathrm{Mu}$ and other transposable elements. Proceedings of the National Academy of Sciences of the United States of America 76, 1933-1937.

Shapiro, J. A. \& Machattie, L. A. (1978). Integration and excision of prophage $\lambda$ mediated by the IS 1 element. Cold Spring Harbor Symposia on Quantitative Biology 43, 1135-1142.

Silver, L., Chandler, M., Lane, H. E. D. \& Caro, L. (1980). Production of extrachromosomal $r$ determinant circles from integrated R 100-1: involvement of the E. coli recombination system. Molecular and General Genetics 179, 565-571.

SOUTHERn, E. M. (1975). Detection of specific 
sequences among DNA fragments separated by gel electrophoresis. Journal of Molecular Biology 98, 503-517.

W ANDERSMAN, C. \& YARMOLINSKY, M. (1977). Bipartite control of immunity conferred by the related heteroimmune plasmid prophages, $\mathrm{P} 1$ and $\mathrm{P} 7$ (formerly $\phi$ Amp). Virology 77, 386-400.

Wood, W. B. (1966). Host specificity of DNA produced by Escherichia coli: bacterial mutations affecting the restriction and modification of DNA. Journal of Molecular Biology 16, 118-133.
YARMOLINSKY, M. (1977). Genetic and physical structure of bacteriophage P1 DNA. In DNA Insertion Elements, Plasmids, and Episomes, pp. 721-732. Edited by A. I. Bukhari, J. A. Shapiro \& S. L. Adhya. New York: Cold Spring Harbor Laboratory.

YUN, T. \& VAPNEK, D. (1977). Electron microscopic analysis of bacteriophages $\mathrm{P} 1, \mathrm{P} 1 \mathrm{Cm}$ and $\mathrm{P} 7$. Determination of genome sizes, sequence homology, and location of antibiotic-resistance determinants. Virology 77, 376-385. 